ISSN 1392-3196 / e-ISSN 2335-8947

Zemdirbyste-Agriculture, vol. 104, No. 1 (2017), p. 15-22

DOI 10.13080/z-a.2017.104.003

\title{
Reaction of winter spelt cultivars to reduced tillage system and chemical plant protection
}

\author{
Sylwia ANDRUSZCZAK \\ University of Life Sciences in Lublin \\ Akademicka 13, 20-950 Lublin, Poland \\ E-mail: sylwia.andruszczak@up.lublin.pl
}

\begin{abstract}
A three-factor field experiment evaluated grain yield, yield components and some grain quality traits (Zeleny sedimentation value and the contents of protein, gluten, starch, carotene, lutein, zeaxanthin and amino acids) of eight winter spelt cultivars as influenced by the tillage system (conventional and reduced tillage) and chemical plant protection (application of two herbicides: Mustang 306 SE and Attribut 70 WG, a fungicide Alert 375 SC and a growth regulator Stabilan $750 \mathrm{SL}$ ). Plots without the use of plant protection chemicals were the control treatment.

Yield and chemical composition of spelt grain were most dependent on the genetic determinants of the individual cultivar, but it is possible to affect yield quantity and quality through agronomic factors. The highest grain yields were produced by the cultivars 'Badengold', 'Ceralio', 'Frankenkorn' and 'Ostro', while in terms of grain quality the most valuable were cvs. 'Ceralio' and 'Ostro'. Under the conditions of reduced tillage system, the spelt grain yields were significantly lower than under the conventional tillage, but the evaluated cultivars responded differently to this factor. The highest reduction in yield compared to conventional soil tillage was found for the cvs. 'Oberkulmer Rotkorn', 'Spelt I.N.Z.' and 'Schwabenkorn', while the lowest one for cv. 'Ceralio'. On the other hand, the ploughless tillage contributed to a significant increase in Zeleny sedimentation value as well as in grain protein and gluten content, whereas the starch content decreased. At the same time, the grain amino acid content was at a similar level under both tillage systems. Chemical plant protection significantly increased the Zeleny sedimentation value and the grain protein content. The number of ears per $1 \mathrm{~m}^{2}$ and grain yields also increased and the highest yield increase compared to the treatment without chemical plant protection products was achieved by the cvs. 'Schwabenkorn', 'Spelt I.N.Z.' and 'Frankenkorn'.
\end{abstract}

Key words: amino acids content, grain quality, herbicides, ploughless tillage, yield structure.

\section{Introduction}

In recent years, a trend towards increasing biological diversity in plant food materials has manifested itself and therefore a return to traditional species grown in the past can be observed (Moudrý et al., 2011). One of the oldest cereals used by humans is spelt. Starting from the Bronze Age, spelt was one of more important crop plants in Europe. However, its low yield potential and the difficulties with grain dehulling became the reason for the abandonment of its cultivation in favour of more productive common wheat varieties (Kohajdová, Karovičová, 2008). Currently, spelt occupies a small area and on a larger scale it is grown in Germany, Austria and Switzerland. Nevertheless, numerous scientific reports indicate that spelt contains many valuable nutrients and hence the interest in this cereal has been increasing from year to year. Spelt grain is a rich source of dietary fibre, silicon, mineral nutrients and group B vitamins. Compared to common wheat, it contains more protein, gluten and fat, but less fibre. Moreover, it contains substances with the antioxidant properties (Kohajdová, Karovičová, 2008;
Gawlik-Dziki et al., 2012; Jablonskytė-Raščè et al., 2013; Kraska et al., 2013).

Information can be found in the literature that spelt wheat is a low-input crop that does not require intensive protection to be used (Kwiatkowski et al., 2015). It is characterized by a rather high level of resistance to ear and grain infection by fungal pathogens (Vučković et al., 2013) and better competes with weeds than common wheat (Feledyn-Szewczyk, 2009). Although spelt is considered to be a model crop for the needs of organic farming, the research of some authors reveals that it responds well to the intensification of cultivation. According to Rachoń et al. (2009) and Andruszczak et al. (2011), under full chemical protection conditions grain yields are higher, while the nutritional value of grain is comparable to grain harvested from crops without pesticide application (Kwiecińska-Poppe et al., 2011).

Due to its valuable chemical composition, spelt grain and products produced from it can be a diet component alternative to other cereals. Nevertheless, 
the low yield potential is an important factor that reduces the spelt acreage and therefore it is necessary to draw attention to the agronomic factors whose optimization would allow us to increase yields and make them stable. The existing research has primarily focused on the evaluation of the suitability of spelt for organic farming, but there is little information on the impact of cropping intensification on spelt yields and grain chemical composition.

Given the above, the current study was aimed to evaluate the response of eight winter spelt cultivars to chemical crop protection used under conventional tillage and reduced tillage conditions.

\section{Materials and methods}

Experimental design. In 2009-2011, a field experiment was carried out at the Bezek Experimental Farm located near the city of Chełm $\left(51^{\circ} 19^{\prime} \mathrm{N}, 23^{\circ} 25^{\prime} \mathrm{E}\right)$, Poland. The experiment was established on a Rendzic Phaeozem (WRB, 2006) originating from cretaceous bedrock, with the texture of loam - the textural class according to the Polish Society of Soil Science (2009).

A three-factor field experiment evaluated the grain yield, yield components and chemical composition of eight winter spelt cultivars 'Badengold', 'Ceralio', 'Frankenkorn', 'Oberkulmer Rotkorn', 'Ostro', 'Schwabenkorn', 'Schwabenspeltz' and 'Spelt I.N.Z.', as influenced by the soil tillage system (conventional and reduced) and plant protection chemicals. The experiment was set up in a split-plot design with three replications and the harvested plot area was $8 \mathrm{~m}^{2}$. Common wheat was the forecrop for the experiment, while spelt cultivars were grown in monoculture. In the conventional tillage system, after the harvest of the previous crop, skimming and harrowing were done. Pre-sowing ploughing with harrowing was carried out three weeks before spelt sowing. The field was also harrowed immediately before sowing. In the reduced tillage treatment, cultivating and harrowing were done after the harvest of the previous crop and subsequently cultivating and harrowing were repeated before sowing. Spelt spikelets were sown in mid-October at a rate of $350 \mathrm{~kg}$ per hectare. Mineral fertilization of spelt was as follows: N $60(20+40)$, P 26.2 and $\mathrm{K} 83 \mathrm{~kg} \mathrm{ha}^{-1}$.

Chemical plant protection included the application of two herbicides, fungicide and growth regulator. The herbicides Mustang $306 \mathrm{SE}$ (a.i. $6.25 \mathrm{~g} \mathrm{l}^{-1}$ florasulam, $300 \mathrm{~g} \mathrm{l}^{-1}$ 2,4-D EHE) and Attribut $70 \mathrm{WG}$ (a.i. $70 \%$ propoxycarbazone, methyl ester of 2-benzoic acid sodium salt) were applied in spring at the tillering stage (BBCH 24-29) at the rates of $0.41 \mathrm{ha}^{-1}$ and $60 \mathrm{~g} \mathrm{ha}^{-1}$, respectively. The fungicide Alert $375 \mathrm{SC}$ (a.i. $125 \mathrm{~g} \mathrm{l}^{-1}$ flusilazole, $250 \mathrm{~g} \mathrm{l}^{-1}$ carbendazim) at a rate of $1 \mathrm{l} \mathrm{ha}^{-1}$ and the growth regulator Stabilan $750 \mathrm{SL}$ (a.i. $750 \mathrm{~g} \mathrm{l}^{-1}$ chlormequat chloride) at a rate of $21 \mathrm{ha}^{-1}$ were applied at the stem elongation stage (BBCH 32-34). Plots where no chemical plant protection agents had been used served as the control treatment.

Before harvesting, the height of spelt plants and the length of ears were measured on 30 randomly chosen plants in each plot, and also the number of ears in the area of $1 \mathrm{~m}^{2}$ was calculated. In the ear sample collected from each plot, grain number and weight per ear were determined. After threshing, done with a laboratory thresher LD 180 (Wintersteiger, Austria), the weight of 1000 grains, as well as grain yield was evaluated.

Meteorological conditions. The total rainfall from April to August in all experimental years was higher than the long-term average. In June 2009, July and August 2010 as well as in July 2011, the total rainfall significantly exceeded the long-term average for these months. The mean air temperature in all years was higher, compared with the long-term average (Fig. 1).
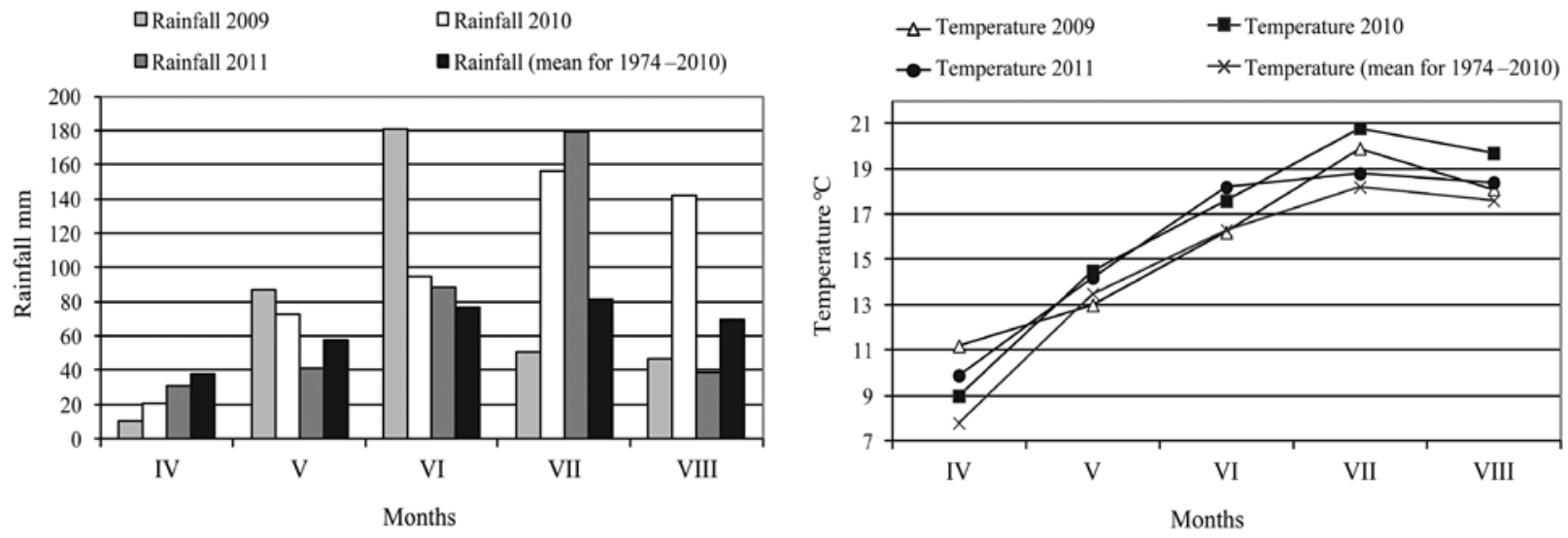

Figure 1. Rainfall and air temperature in April-August in 2009-2011 as compared to the long-term means (19742010) according to the Meteorological Station at Bezek, Poland

Chemical analyses of grain. Chemical composition of spelt grain was determined based on composite samples from each plot. The total protein, gluten and starch content in the grain, as well as Zeleny sedimentation index was determined with NIR technique, using the phenomenon of light reflection within the range of near infrared of the analyzed substance, with the use of a computer transmission analyzer of the whole grain Omeg Analizer G (Bruins Instruments, Germany).
Total carotenoids were extracted from $10 \mathrm{~g}$ of grain with a mixture of methanol/ethyl acetate/petroleum ether $(1: 1: 1, \mathrm{v} / \mathrm{v} / \mathrm{v})$ containing $0.1 \%$ BHT (butylated hydroxytoluene) in ethyl acetate as antioxidant and calcium carbonate. The extract was dissolved in diethyl ether and saponified with $30 \%$ methanolic $\mathrm{KOH}$ (potassium hydroxide) at a room temperature in the dark for $16 \mathrm{~h}$. For the removal of soaps and alkalis, the solution was washed many times with a sodium chloride-saturated 
solution and distilled water. The organic layer containing carotenoids was dried over anhydrous sodium sulphate and evaporated to dryness. The samples were kept under nitrogen, at $-20^{\circ} \mathrm{C}$ until use and were filtered through $0.45 \mathrm{~mm}$ Whatman filters prior high-performance liquid chromatography (HPLC) analysis.

For analysis $20 \mu \mathrm{L}$ of the sample were used. Collected samples were dosed three times and the results averaged. The purified extracts were separated and quantified by HPLC (Knauer WellChrom, Germany) equipped with YMC C30 $10 \times 4.6 \mathrm{~mm}, 3 \mathrm{~m}$ precolumn and YMC-C $30250 \times 4.6 \mathrm{~mm}, 5 \mathrm{~m}$ column (YMC Europe $\mathrm{GmbH}$, Germany). The pigments were eluted by methanol: MTBE (methyl tert-butyl ether) (89:11) at a flow rate of $1 \mathrm{ml} \mathrm{min}^{-1}$. The absorbance was measured at the wavelength of $450 \mathrm{~nm}$. Carotenoids were identified, based on retention times of the lutein, zeaxantin and $\beta$-carotene true standards (Sigma-Aldrich, USA) and quantitatively determined by comparing the size (surface area) of the corresponding reference peak.

Amino acid content was determined by an AAA400 amino acid analyzer, manufactured by INGOS Ltd. (Czech Republic), using ion-exchange chromatography with post-column ninhydrin derivatization. The prepared sample was injected into the column of the amino acid analyzer where the separation occurred. The individual analyst was derivatized in the reactor into coloured aminoninhydrin complexes. Identification was performed with a photometric detector.

Statistical analysis. The obtained results were statistically analysed by four-way analysis of variance $(A N O V A)$ and least significant differences were calculated using Tukey's confidence half-intervals with an error rate of 5\%. Software ARStat developed by the Computing Centre of the University of Life Sciences in Lublin was used for the calculations.

\section{Results and discussion}

Spelt is characterized by high variation in morphological characters and ear productivity, and each cultivar shows specific characters determined by the genetic factor. The present study demonstrated a significantly differential effect of the cultivar on spelt grain yield and its components (Table 1). Regardless of the tillage system and chemical crop protection, the cvs. 'Ostro', 'Spelt I.N.Z.' and 'Oberkulmer Rotkorn' reached the highest crop height, whereas cvs. 'Schwabenspelz', 'Frankenkorn' and 'Badengold' were significantly shorter. The number of ears per $1 \mathrm{~m}^{2}$ ranged from 375 to 463 and was in general lower (349-759 ears per $\left.1 \mathrm{~m}^{2}\right)$ than in the study by Pospišil et al. (2011), but higher (356-368 ears per $1 \mathrm{~m}^{2}$ ) than that found by Sulewska et al. (2008). Cultivars 'Ostro' and 'Oberkulmer Rotkorn' produced most ears per unit area, whereas cvs. 'Schwabenspelz' and 'Badengold' were characterized by the lowest ear density.

In the research by Jablonskytė-Raščè et al. (2013), the spelt ear length in cv. 'Frankenkorn' ranged from 7.6 to $14.2 \mathrm{~cm}$, depending on foliar fertilizers used. In the present study, the value of this trait for the eight spelt cultivars varied less and was within the range of $9.9-11.5 \mathrm{~cm}$. The longest ears were found in cv. 'Ceralio', while in turn cvs. 'Spelt I.N.Z.' and 'Schwabenkorn' produced the shortest ears. At the same time, these cultivars were characterized by the lowest yield per ear as well as a relatively low number of grains per ear and 1000 grain weight. The obtained results find confirmation in the study by Świeca et al. (2014). These authors found that among six spelt cultivars, grain of cvs. 'Schwabenkorn' and 'Spelt I.N.Z.' had the lowest weight and diameter.

The 1000 grain weight in the evaluated spelt cultivars was higher $(30.2-32.3 \mathrm{~g})$ than that reported by

Table 1. Grain yield and some features of spelt plants as influence by the experimental factors (mean for 2009-2011)

\begin{tabular}{|c|c|c|c|c|c|c|c|}
\hline Treatment & $\begin{array}{l}\text { Plant height } \\
\mathrm{cm}\end{array}$ & $\begin{array}{l}\text { Ear number } \\
\text { per } 1 \mathrm{~m}^{2}\end{array}$ & $\begin{array}{l}\text { Ear length } \\
\mathrm{cm}\end{array}$ & $\begin{array}{l}\text { Grain number } \\
\text { per ear }\end{array}$ & $\begin{array}{l}\text { Grain weight of } \\
\text { per ear } g\end{array}$ & $\begin{array}{l}1000 \text { grains } \\
\text { weight } \mathrm{g}\end{array}$ & $\begin{array}{l}\text { Grain yield } \\
\mathrm{Mg} \mathrm{ha}^{-1}\end{array}$ \\
\hline \multicolumn{8}{|c|}{ Cultivar } \\
\hline 1. Badengold & 106 & 399 & 11.4 & 34.0 & 1.33 & 39.3 & 4.74 \\
\hline 2. Ceralio & 115 & 407 & 11.5 & 27.9 & 1.21 & 44.4 & 4.69 \\
\hline 3. Frankenkorn & 108 & 429 & 10.3 & 24.9 & 1.08 & 43.5 & 4.48 \\
\hline 4. Oberkulmer Rotkorn & 120 & 459 & 10.7 & 19.4 & 0.92 & 47.9 & 3.96 \\
\hline 5. Ostro & 123 & 463 & 11.2 & 20.0 & 1.00 & 50.7 & 4.36 \\
\hline 6. Schwabenkorn & 119 & 406 & 10.2 & 19.9 & 0.83 & 41.5 & 3.21 \\
\hline 7. Schwabenspelz & 111 & 375 & 11.3 & 28.6 & 1.22 & 43.3 & 4.18 \\
\hline 8. Spelt I.N.Z. & 121 & 408 & 9.9 & 20.0 & 0.83 & 42.4 & 3.14 \\
\hline $\mathrm{LSD}_{0.05}$ & 5.8 & 42.7 & 0.61 & 3.22 & 0.13 & 1.76 & 0.520 \\
\hline \multicolumn{8}{|c|}{ Soil tillage system } \\
\hline Conventional (CT) & 115 & 437 & 10.6 & 24.1 & 1.03 & 43.3 & 4.43 \\
\hline Reduced (RT) & 116 & 399 & 11.0 & 24.6 & 1.07 & 44.9 & 3.75 \\
\hline $\mathrm{LSD}_{0.05}$ & ns & 13.8 & 0.20 & ns & ns & 0.57 & 0.170 \\
\hline \multicolumn{8}{|c|}{ Chemical protection } \\
\hline $\begin{array}{l}\text { Control treatment without } \\
\text { chemical protection (I) }\end{array}$ & 120 & 394 & 10.8 & 24.2 & 1.05 & 44.3 & 3.90 \\
\hline $\begin{array}{l}\text { Treatment with plant } \\
\text { protection chemicals (II) }\end{array}$ & 111 & 442 & 10.8 & 24.5 & 1.06 & 44.0 & 4.29 \\
\hline $\mathrm{LSD}_{0.05}$ & 1.9 & 13.8 & $\mathrm{~ns}$ & $\mathrm{~ns}$ & ns & ns & 0.170 \\
\hline
\end{tabular}

ns - not significant 
Sulewska et al. (2008), but it was similar (38.3-50.1 g) to that found in the research by Lacko-Bartošová et al. (2010). Among the spelt cultivars in question, the largest grains were produced by cv. 'Ostro', which was also confirmed by Świeca et al. (2014) in their study. Moudrý (1999), however, classified this cultivar in the group with the lowest 1000 grain weight, at the same indicating that the value of this trait depends not only on the genotype, but primarily on the weather conditions during growth. In the present study, cv. 'Badengold' had the lowest 1000 grain weight. Nonetheless, this cultivar was characterized by the highest grain number and weight per ear and the values of these traits were by $18.9-75.3 \%$ and $9.0-60.2 \%$, respectively higher compared to the other cultivars.

In the opinion of Sulewska et al. (2008), spelt has a lower yield potential than common wheat, which is determined by the shortened period of generative growth and the related lower number of kernels per ear. Under the conditions of the present study, spelt produced yields of 3.14-4.74 $\mathrm{Mg} \mathrm{ha}^{-1}$. In the study of Lacko-Bartošová et al. (2010), the grain yields obtained for eight spelt cultivars were much higher, notably $5.38-6.76 \mathrm{Mg} \mathrm{ha}^{-1}$, whereas in the experiment conducted by Kwiatkowski et at. (2015) they were $2.69-2.97 \mathrm{Mg} \mathrm{ha}^{-1}$. In the group of the eight spelt cultivars evaluated, cv. 'Badengold' produced the highest yields, followed by cvs. 'Ceralio' and 'Frankenkorn', whereas cvs. 'Spelt I.N.Z.' and 'Schwabenkorn' showed the lowest yields during the three-year study period. In another study conducted by Andruszczak et al. (2011) concerning the optimization of mineral fertilization of spelt and chemical crop protection, the grain yields of cvs. 'Schwabenkorn' and 'Spelt I.N.Z.' were much higher (40.7 and $44.45 \mathrm{Mg} \mathrm{ha}^{-1}$ ), which was probably attributable to the different agronomic conditions.

The ear length and 1000 grain weight of spelt were significantly higher under reduced tillage conditions (respectively by $3.8 \%$ and $3.7 \%$ ), but the ear density per unit area (by 9.5\%) was found to be higher in the conventional tillage system. As a result, the spelt grain yields obtained under the no-tillage system were significantly lower, on average by $15.3 \%$, compared to conventional tillage. In a study carried out in Switzerland, Berner et al. (2008) demonstrated that under reduced tillage conditions spelt produced an $8 \%$ lower yield than in the conventional tillage treatment. In the present study, all the spelt cultivars evaluated showed a decrease in yield under the influence of reduced tillage, but the differences obtained were not statistically confirmed (Fig. 2). The cvs. 'Oberkulmer Rotkorn', 'Spelt I.N.Z.' and 'Schwabenkorn' responded most strongly (a reduction in yield by $28.6 \%, 24.3 \%$ and $22.7 \%$, respectively, relative to conventional tillage), whereas the lowest differences in yield were found in the case of cv. 'Ceralio' (4.8\%).

Regardless of the cultivar and tillage system, the use of two herbicides, fungicide protection and a retardant contributed to an increase in spelt grain yield by $10 \%$ compared to the control treatment, but this increase was only determined by the higher ear density (Table 1). On the other hand, this research found no significant effect of chemical crop protection on ear length, grain number and weight per ear, and 1000 grain weight. In the study by Rachoń et al. (2009), complex chemical protection of winter spelt breeding lines, which included the application of a seed dressing, two herbicides, a fungicide, a growth regulator and an insecticide, significantly increased the

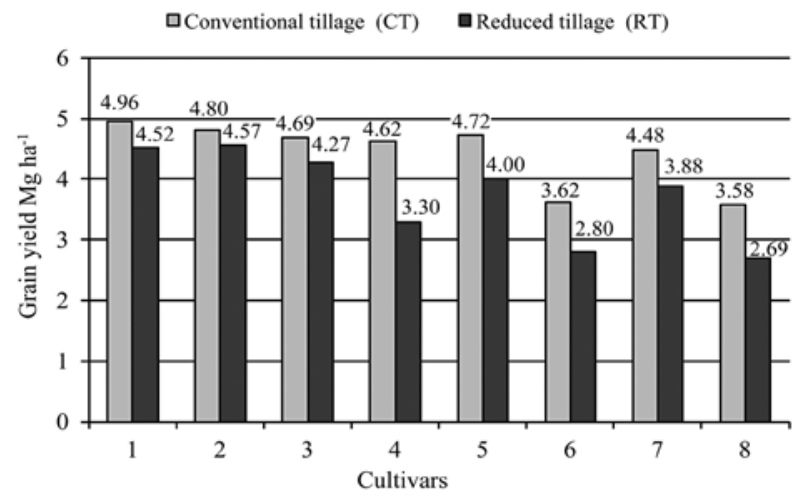

1 - Badengold, 2 - Ceralio, 3 - Frankenkorn, 4 - Oberkulmer Rotkorn, 5 - Ostro, 6 - Schwabenkorn, 7 - Schwabenspelz, 8 - Spelt I.N.Z.

Figure 2. The effect of soil tillage system on grain yield of winter spelt cultivars (mean for 2009-2011)

number and weight of grains per ear by $8.6 \%$ and $9.2 \%$, respectively, compared to minimal protection (a seed dressing and a herbicide), whereas the grain yields increased by on average $17.7 \%$.

Generally, the evaluated spelt cultivars positively responded to chemical crop protection, but the obtained increase in grain yield relative to the control treatment without protection was statistically insignificant (Fig. 3). Irrespective of the tillage system, the highest increase in yield under the influence of the chemical crop protection used was found in the cvs. 'Schwabenkorn', 'Spelt I.N.Z.' and 'Frankenkorn'(by 15.8, 15.5 and $14.4 \%$, respectively). Cultivars 'Badengold' and 'Ostro' responded more poorly to chemical crop protection $(11.8 \%$ and $10.9 \%)$, whereas the grain yields of cv. 'Schwabenspelz' in both treatments (with and without chemical protection) were at a similar level. The previous study on two winter spelt cultivars also revealed a varied response of these cultivars to chemical crop protection (Andruszczak et al., 2011). In the chemically treated plots, cv. "Schwabenkorn" gave significantly higher grain yields than in the control treatment without protection, but in the case of cv. 'Spelt I.N.Z.' chemical crop protection did not have a significant effect on the grain yield obtained. In the opinion of Kieloch and Sumisławska (2012), the varied response

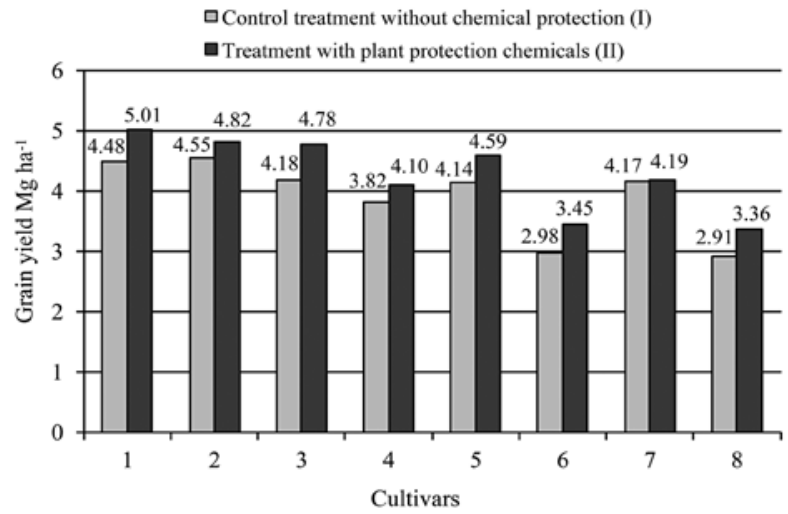

1 - Badengold, 2 - Ceralio, 3 - Frankenkorn, 4 - Oberkulmer Rotkorn, 5 - Ostro, 6 - Schwabenkorn, 7 - Schwabenspelz, 8 - Spelt I.N.Z.

Figure 3. The effect of chemical protection on grain yield of winter spelt cultivars (mean for 2009-2011) 
of winter wheat cultivars to herbicides is attributable to the genetic properties of a given cultivar, but it can be strongly modified by soil and climate conditions as well as by the level of agronomic practices.

The spelt cultivars compared significantly differed in terms of grain protein content and the amount of protein ranged from $14.1 \%$ to $17.4 \%$ (Table 2 ). In the study by Jablonskytė-Rašče et al. (2013), depending on the nutrition conditions and year, the content of this component in spelt grain was similar to that in the present study (14.9-16.7\%). Much lower protein contents were showed by Świeca et al. (2014) - 9.8-12.5\%, as well as by Wojtkowiak and Stępień (2015) - 12.4-13.5\%, which could have been due to the cultivar factors, the effect of location or agronomic factors. In the group of evaluated cultivars, cv. 'Ostro' contained most protein. A similar protein content was demonstrated for this cultivar by Pospišil et al. (2011). Moreover, cv. 'Ostro' showed the highest gluten content and the highest Zeleny sedimentation value. In turn, the lowest values of the traits in question were found in the case of cv. 'Badengold'.

This study revealed high variation in the grain content of $\beta$-carotene in the spelt cultivars compared, but its amount was higher than that reported by Kandlakunta et al. (2008) for common wheat. In the study by AbdelAal and Rabalski (2008), the lutein content in grain of

Table 2. Chemical composition of spelt grain as influenced by experimental factors (mean for 2009-2011)

\begin{tabular}{|c|c|c|c|c|c|c|c|}
\hline Treatment & $\begin{array}{l}\text { Protein } \\
\%\end{array}$ & $\begin{array}{c}\text { Gluten } \\
\%\end{array}$ & $\begin{array}{l}\text { Starch } \\
\%\end{array}$ & $\begin{array}{c}\text { Zeleny sedimentation } \\
\text { index } \\
\mathrm{Ml}\end{array}$ & $\begin{array}{c}\beta \text {-carotene } \\
\mu \mathrm{g} \mathrm{g}^{-1}\end{array}$ & $\begin{array}{l}\text { Lutein } \\
\mu \mathrm{g} \mathrm{g}^{-1}\end{array}$ & $\begin{array}{c}\text { Zeaxanthin } \\
\mu \mathrm{g} \mathrm{g}^{-1}\end{array}$ \\
\hline \multicolumn{8}{|c|}{ Cultivar } \\
\hline 1. Badengold & 14.1 & 28.1 & 51.0 & 53.3 & 0.06 & 0.71 & 0.04 \\
\hline 2. Ceralio & 16.1 & 34.1 & 49.5 & 62.7 & 0.08 & 1.20 & 0.10 \\
\hline 3. Frankenkorn & 15.2 & 31.3 & 50.3 & 56.1 & 0.06 & 1.20 & 0.05 \\
\hline 4. Oberkulmer Rotkorn & 16.4 & 33.5 & 50.2 & 63.5 & 0.10 & 1.40 & 0.06 \\
\hline 5. Ostro & 17.4 & 36.8 & 49.4 & 68.3 & 0.08 & 1.00 & 0.05 \\
\hline 6. Schwabenkorn & 15.9 & 32.1 & 50.3 & 60.4 & 0.07 & 1.40 & 0.06 \\
\hline 7. Schwabenspelz & 15.4 & 31.9 & 50.2 & 58.9 & 0.05 & 0.75 & 0.05 \\
\hline 8. Spelt I.N.Z. & 14.9 & 29.4 & 49.9 & 58.2 & 0.07 & 1.15 & 0.07 \\
\hline $\mathrm{LSD}_{0.05}$ & 0.60 & 1.81 & ns & 3.24 & ns & 0.400 & 0.041 \\
\hline \multicolumn{8}{|c|}{ Soil tillage system } \\
\hline Conventional (CT) & 14.9 & 30.0 & 50.6 & 56.4 & - & - & - \\
\hline Reduced (RT) & 16.4 & 34.3 & 49.6 & 63.9 & - & - & - \\
\hline $\mathrm{LSD}_{0.05}$ & 0.19 & 0.58 & 0.84 & 1.05 & - & - & - \\
\hline \multicolumn{8}{|c|}{ Chemical protection } \\
\hline $\begin{array}{l}\text { Control treatment without } \\
\text { chemical protection (I) }\end{array}$ & 15.6 & 31.8 & 50.1 & 59.6 & - & - & - \\
\hline $\begin{array}{l}\text { Treatment with plant } \\
\text { protection chemicals (II) }\end{array}$ & 15.8 & 32.4 & 50.2 & 60.7 & - & - & - \\
\hline $\mathrm{LSD}_{005}$ & 0.19 & $\mathrm{~ns}$ & $\mathrm{~ns}$ & 1.05 & - & - & - \\
\hline
\end{tabular}

ns - not significant

three winter spelt cultivars was at a level of $1.3-2.1 \mu \mathrm{g} \mathrm{g}^{-1}$. Ziegler et al. (2015) in spelt grain of cvs. 'Oberkulmer Rotkorn' and 'Schwabenkorn' obtained a similar lutein content ( 1.54 and $\left.1.51 \mu \mathrm{g} \mathrm{g}^{-1}\right)$ relative to the values found in the present study, whereas for cvs. 'Badengold' and 'Frankenkorn' it was higher (1.51 and $\left.1.28 \mu \mathrm{g} \mathrm{g}^{-1}\right)$. The zeaxanthin content in spelt grain ranged from $0.04 \mu \mathrm{g} \mathrm{g}^{-1}$ (cv. 'Badengold') to $0.10 \mu \mathrm{g} \mathrm{g}^{-1}$ (cv. 'Ceralio'). Brandolini et al. (2015) showed a much higher content $\left(0.40 \mu \mathrm{g} \mathrm{g}^{-1}\right)$ of this component in spelt grain.

Under conventional tillage system, regardless of the other experimental factors, spelt grain had a significantly lower content of protein and gluten as well as a lower Zeleny sedimentation value than in the treatment where reduced tillage was used. At the same time, grain was found to have significantly more starch in the conventional tillage treatment. The opinions on the effect of tillage system on the technological value of cereal grains are divided. Woźniak (2009) proves that reduced tillage contributes to a decrease in the content of protein and wet gluten as well as in grain test weight of spring wheat. In the study of Kraska et al. (2014), in turn, the tillage systems caused slight differences in the quality characteristics of spring wheat grain. Similar conclusions also arise from the research by Peigné et al. (2014).
Chemical crop protection that included the application of two herbicides, a fungicide, and a growth regulator significantly increased the Zeleny sedimentation value and the grain protein content, but it had no effect on the gluten and starch content. The existing research on this topic indicates that chemical crop protection does not negatively affect the quality of yields (Mäder et al., 2007; Zorb et al., 2009). The deterioration in some quality parameters is associated with the simultaneous impact of climate and soil conditions and a negative response of wheat cultivars to the chemical applied (Kieloch, Sumisławska, 2012). Rachoń et al. (2015) demonstrated that the intensification of chemical plant protection beneficially affected the chemical composition of spelt, increasing the grain protein content, while the study by Kwiecińska-Poppe et al. (2011) revealed that there was no such relationship.

Kwiatkowski et al. (2015) showed spelt to be characterized by higher content of nearly all amino acids compared to common wheat grain. In the present experiment, cv. 'Schwabenkorn' produced the most valuable grain in terms of amino acid content. Regardless of the agronomic factors, among the eight spelt cultivars it exhibited the highest content of almost all essential amino acids (except for arginine and threonine) (Fig. 4) 

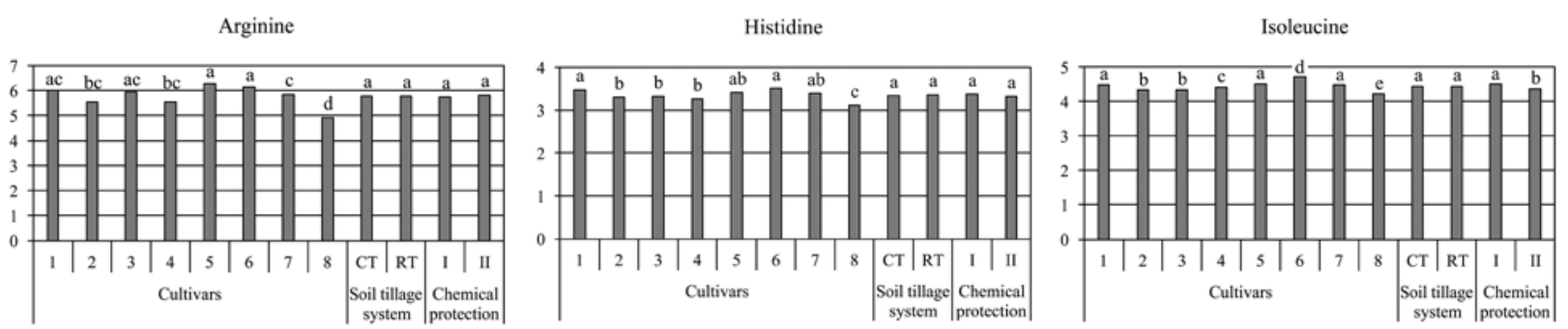

Leucine

Lysine
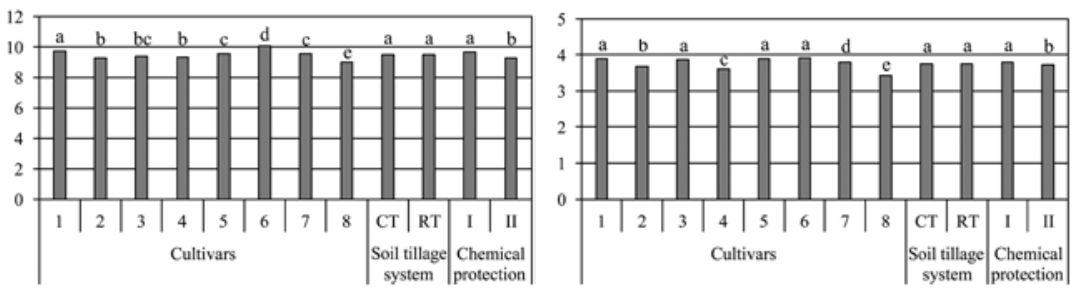

Methionine

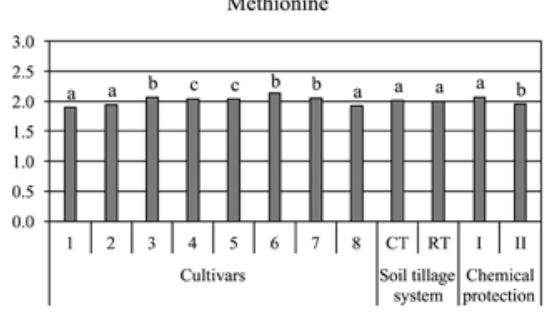

Phenylalanine

Threonine
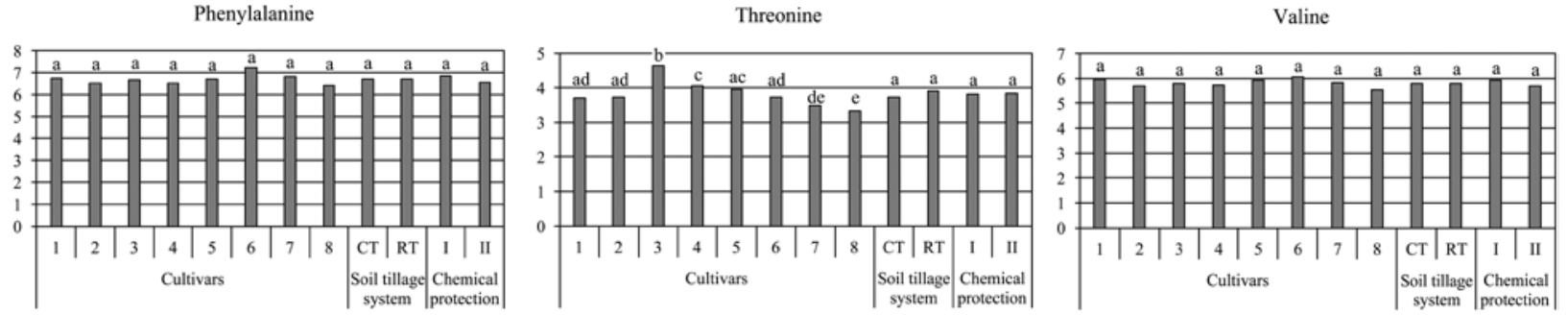

Note. Different small letters above columns indicate significant differences $(p<0.05) ; 1$ - Badengold, 2 - Ceralio, 3 - Frankenkorn, 4 - Oberkulmer Rotkorn, 5 - Ostro, 6 - Schwabenkorn, 7 - Schwabenspelz, 8 - Spelt I.N.Z.; CT - conventional tillage, RT reduced tillage; I - without chemicals, II - with chemicals.

Figure 4. Essential amino acids content in spelt grain as influenced by cultivar, soil tillage system and chemical protection $\left(\mathrm{mg} \mathrm{g}^{-1}\right)$ (mean for 2009-2011)
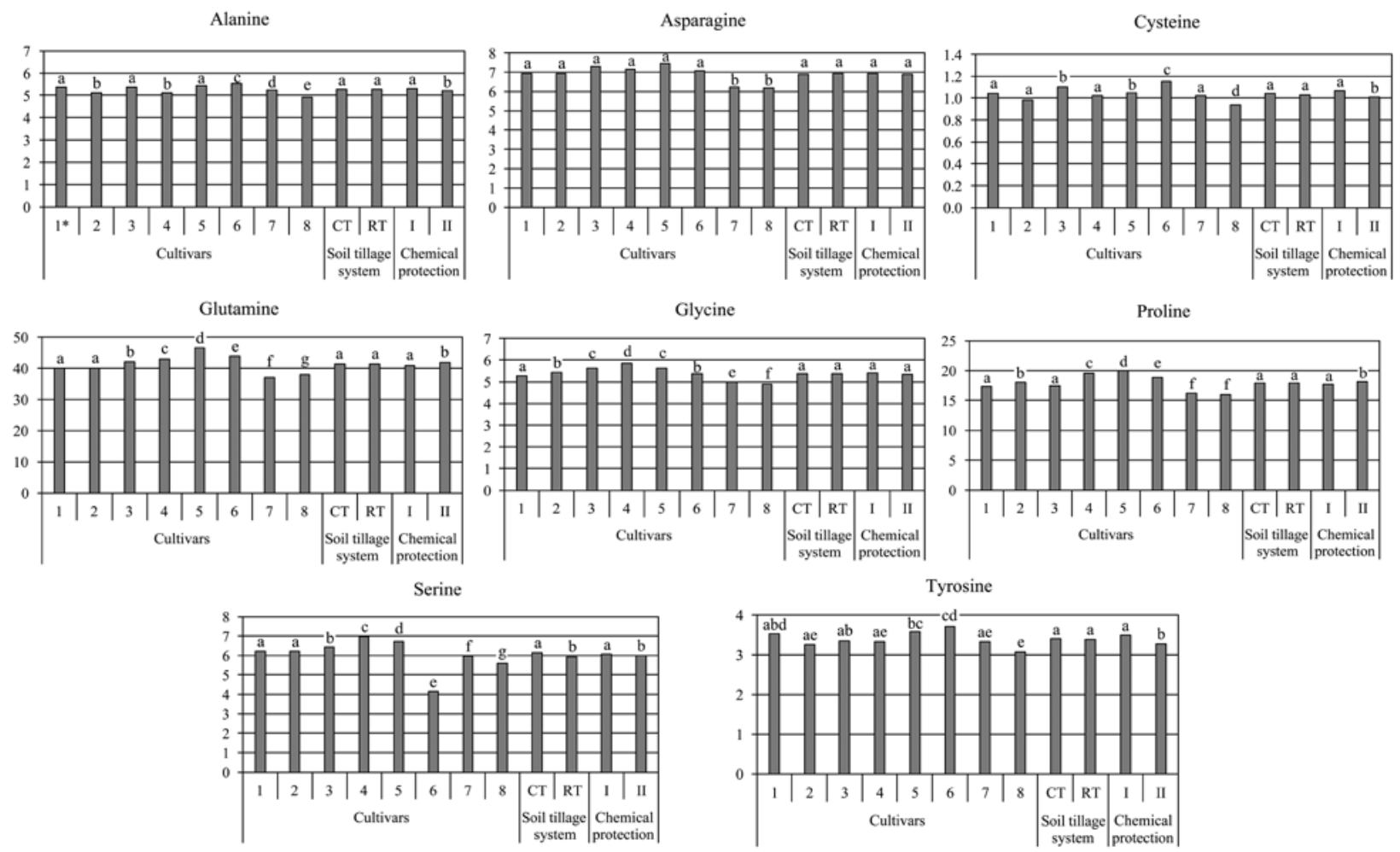

Note. Different small letters above columns indicate significant differences $(p<0.05) ; 1$ - Badengold, 2 - Ceralio, 3 - Frankenkorn, 4 - Oberkulmer Rotkorn, 5 - Ostro, 6 - Schwabenkorn, 7 - Schwabenspelz, 8 - Spelt I.N.Z.; CT - conventional tillage, RT reduced tillage; I - without chemicals, II - with chemicals.

Figure 5. Nonessential amino acids content in spelt grain as influenced by cultivar, soil tillage system and chemical protection $\left(\mathrm{mg} \mathrm{g}^{-1}\right)$ (mean for 2009-2011) 
and also of non-essential amino acids such as alanine, cysteine and tyrosine (Fig. 5).

The use of reduced tillage did not result in differences in the content of amino acids (except for serine) in spelt grain and their amount under the conventional tillage and reduced tillage systems was at a similar level. On the other hand, the study revealed a trend towards a slight decrease in grain amino acid content as affected by the chemicals used.

\section{Conclusions}

1. Spelt yield and grain chemical composition are primarily determined by the individual traits of a given cultivar, but it is possible to affect yield quantity and quality through agronomic factors. Under the conditions of the present study, the highest yields were produced by the cvs. 'Badengold', 'Ceralio', 'Frankenkorn' and 'Ostro'. At the same time, cvs. 'Ceralio' and 'Ostro' distinguished themselves in terms of grain quality.

2. Reduced tillage (RT) system contributed to a significant decrease in spelt grain yield, but the evaluated cultivars showed a varied response to this factor. The highest reduction in yield under the influence of reduced tillage was found in the case of the cvs. 'Oberkulmer Rotkorn', 'Spelt I.N.Z.' and 'Schwabenkorn' (by 28.6, 24.3 and $22.7 \%$, respectively), while the lowest differences in yield were observed for cv. 'Ceralio' $(4.8 \%)$.

3. In the treatment with reduced tillage system, spelt grain had a significantly higher content of protein and gluten as well as a higher Zeleny sedimentation value compared to conventional tillage (CT), but the grain starch content decreased. At the same time, the study did not show any differences in amino acid content as affected by soil tillage system.

4. Compared to the treatment without protection, the application of two herbicides, a fungicide, and a growth regulator significantly increased the Zeleny sedimentation value and the grain protein content. The number of ears per $1 \mathrm{~m}^{2}$ and grain yields also increased, but the highest yield increase was achieved by cvs. 'Schwabenkorn' (15.8\%), 'Spelt I.N.Z.' (15.5\%) and 'Frankenkorn' (14.4\%).

Received 30062016 Accepted 14112016

\section{References}

Abdel-Aal E. S. M., Rabalski I. 2008. Bioactive compounds and their antioxidant capacity in selected primitive and modern wheat species. The Open Agriculture Journal, 2: 7-14 https://doi.org/10.2174/1874331500802010007

Andruszczak S., Kwiecińska-Poppe E., Kraska P., Pałys E. 2011. Yield of winter cultivars of spelt wheat (Triticum aestivum ssp. spelta L.) cultivated under diversified conditions of mineral fertilization and chemical protection. Acta Scientiarum Polonorum, Agricultura, 10 (4): 5-14

Berner A., Hildermann I., Fließbach A., Pfiffner L., Niggli U., Mäder P. 2008. Crop yield and soil fertility response to reduced tillage under organic management. Soil and Tillage Research, 101: 89-96 https://doi.org/10.1016/j.still.2008.07.012

Brandolini A., Hidalgo A., Gabriele S., Heun M. 2015. Chemical composition of wild and feral diploid wheats and their bearing on domesticated wheats. Journal of Cereal
Science, 63: 122-127

https://doi.org/10.1016/j.jcs.2015.03.005

Feledyn-Szewczyk B. 2009. Comparison of the competitiveness of modern and old winter wheat varieties in relation to weeds. Journal of Research and Application in Agriculture Engineering, 54 (3): 60-67

Gawlik-Dziki U., Świeca M., Dziki D. 2012. Comparison of phenolic acids profile and antioxidant potential of six varietes of spelt (Triticum spelta L.). Journal of Agriculture and Food Chemistry, 60 (18): 4603-4612 https://doi.org/10.1021/jf3011239

Jablonskytė-Raščè D., Maikštėnienė S., Mankevičienè A. 2013. Evaluation of productivity and quality of common wheat (Triticum aestivum L.) and spelt (Triticum spelta L.) in relation to nutrition conditions. Zemdirbyste-Agriculture, 100 (1): 45-55 https://doi.org/10.13080/z-a.2013.100.007

Kandlakunta B., Rajendran A., Thingnganing L. 2008. Carotene content of some common (cereals, pulses, vegetables, spices and condiments) and unconventional sources of plant origin. Food Chemistry, 106: 85-89 https://doi.org/10.1016/j.foodchem.2007.05.071

Kieloch R., Sumisławska J. 2012. The influence of herbicides on yield and grain quality of three winter wheat cultivars. Progress in Plant Protection, 52 (2): 266-271 (in Polish)

Kohajdová Z., Karovičová J. 2008. Nutritional value and baking applications of spelt wheat. Acta Scientiarum Polonorum, Technologia Alimentaria, 7 (3): 5-14

Kraska P., Andruszczak S., Kwiecińska-Poppe E., Pałys E. 2013. Effect of chemical crop protection on the content of some elements in grain of spelt wheat (Triticum aestivum ssp. spelta). Journal of Elementology, 1: 79-90

Kraska P., Andruszczak S., Kwiecińska-Poppe E., Pałys E. 2014. The effect of tillage systems and catch crops on the yield, grain quality and health of spring wheat. Acta Scientiarum Polonorum, Agricultura, 13 (1): 21-38

Kwiatkowski C.A., Haliniarz M., Tomczyńska-Mleko M., Mleko S., Kawecka-Radomska M. 2015. The content of dietary fiber, amino acids, dihydroxyphenols and some macro- and micronutrients in grain of conventionally and organically grown common wheat, spelt wheat and proso millet. Agricultural and Food Science, 24: 195-205

Kwiecińska-Poppe E., Andruszczak S., Kraska P., Pałys E. 2011. The influence of chemical protection levels on quality of spelt wheat (Triticum spelta L.) grain. Progress in Plant Protection, 51 (2): 986-989 (in Polish)

Lacko-Bartošová M., Korczyk-Szabo J., Ražný R. 2010. Triticum spelta - a specialty grain for ecological farming systems. Research Journal of Agricultural Science, 42 (1): 143-147

Mäder P., Hahn D., Dubois D., Gunst L., Alföldi T., Bergmann H., Oehme M., Amado R., Schneider H., Graf U., Velimirov A., Fließbach A., Niggli U. 2007. Wheat quality in organic and conventional farming: results of a 21 year field experiment. Journal of the Science of Food and Agriculture. 87 (10): 1826-1835 https://doi.org/10.1002/jsfa.2866

Moudrý J. 1999. Productivity of spelt wheat (Triticum spelta L.) spike. Scientia Agriculturae Bohemica, 30 (1): 15-26

Moudrý J., Konvalina P., Stehno Z., Capouchová I., Moudrý J. Jr. 2011. Ancient wheat species can extend biodiversity of cultivated crops. Scientific Research and Essays, 6 (20): 4273-4280 https://doi.org/10.5897/SRE11.928

Peigné J., Messmer M., Aveline A., Berner A., Mäder P., Carcea M., Narducci V., Samson M. F., Thomsen I. K., Celette F., David C. 2014. Wheat yield and quality as influenced by reduced tillage in organic farming. Organic Agriculture, 4: 1-13 https://doi.org/10.1007/s13165-013-0055-x

Polish Society of Soil Science. 2009. Particle size distribution and textural classes of soil and mineral materials - 
classification of Polish Society of Soil Science 2008. Roczniki Gleboznawcze, 60 (2): 5-16 (in Polish)

Pospišil A., Pospišil M., Svečnjak Z., Matotan S. 2011. Influence of crop management upon the agronomic traits of spelt (Triticum spelta L.). Plant, Soil and Environment, 57 (9): 435-440

Rachoń L., Szumiło G., Czubacka M. 2009. Yielding of winter lines of wheat spelt under the differentiated chemical plant protection conditions. Zeszyty Problemowe Postępów Nauk Rolniczych, 542: 427-436 (in Polish)

Rachoń L., Szumiło G., Brodowska M., Woźniak A. 2015. Nutritional value and mineral composition of grain of selected wheat species depending on the intensity of a production technology. Journal of Elementology, 20 (3): 705-715

Sulewska H., Koziara W., Panasiewicz K., Ptaszyńska G. 2008. Yielding of two spelt varieties depending on sowing date and sowing rate in central Wielkopolska conditions. Journal of Research and Applications in Agricultural Engineering, 53 (4): 85-91

Świeca M., Dziki D., Gawlik-Dziki U., Różyło R., Andruszczak S., Kraska P., Kowalczyk D., Pałys E., Baraniak B. 2014. Grinding and nutritional properties of six spelt (Triticum aestivum ssp. spelta L.) cultivars. Cereal Chemistry, 91 (3): $247-254$

https://doi.org/10.1094/CCHEM-02-13-0019-R
Vučković J., Bodroža-Solarov M., Vujić D., Bočarov-Stančić A., Bagi F. 2013. The protective effect of hulls on the occurrence of Alternaria mycotoxins in spelt wheat. Journal of the Science of Food and Agriculture, 93 (8): 1996-2001 https://doi.org/10.1002/jsfa.6005

Wojtkowiak K., Stępień A. 2015. Nutritive value of spelt (Triticum aestivum spp. spelta L.) as influenced by the foliar application of copper, zinc and manganese. ZemdirbysteAgriculture, 102 (4): 389-396 https://doi.org/10.13080/z-a.2015.102.049

Woźniak A. 2009. Quality of grain of spring wheat cv. Koksa in different tillage systems. Acta Agrophysica, 14 (1): 233-241 (in Polish)

WRB. 2006. World reference base for soil resources 2006 . World Soil Resources Reports, 103, FAO, Rome

Ziegler J. U., Wahl S., Wurschum T., Longin C. F. H., Carle R., Schweiggert R. M. 2015. Lutein and lutein esters in whole grain flours made from 75 Genotypes of 5 Triticum species grown at multiple sites. Journal of Agricultural and Food Chemistry, 63 (20): 5061-5071 https://doi.org/10.1021/acs.jafc.5b01477

Zorb C., Niehaus K., Barsch A., Betsche T., Langenkamper G. 2009. Levels of compounds and metabolites in wheat ears and grains in organic and conventional agriculture. Journal of Agricultural and Food Chemistry, 57 (20): 9555-9562 https://doi.org/10.1021/jf9019739

ISSN 1392-3196 / e-ISSN 2335-8947

Zemdirbyste-Agriculture, vol. 104, No. 1 (2017), p. 15-22

DOI $10.13080 /$ z-a.2017.104.003

\title{
Speltos žieminių kviečių veisliụ vertinimas panaudojus minimalų žemès dirbimą ir cheminius augalų apsaugos produktus
}

\author{
S. Andruszczak \\ Liublino gyvybės mokslų universitetas, Lenkija
}

\section{Santrauka}

Trijų veiksnių eksperimente vertintas aštuonių veisliu speltos žieminiu kviečiu grūdų derlius, derliaus komponentai ir kai kurios grūdų kokybės savybès (Zeleny sedimentacijos vertè, baltymų, glitimo, krakmolo, karotino, luteino, zeaksantino ir aminorūgščiu kiekiai), priklausomai nuo žemės dirbimo (tradicinio bei minimaliaus) taikymo ir augalų apsaugos produktų (dviejų herbicidų: Mustang 306 SE ir Attribut 70 WG, fungicido Alert 375 SC bei augimo reguliatoriaus Stabilan $750 \mathrm{SL}$ ) naudojimo. Kontroliniuose laukeliuose augalu apsaugos produktai nenaudoti. Nustatyta, kad speltos kviečių grūdų derlius ir cheminė sudètis labiausiai priklausè nuo veislès genetinių ypatumų, tačiau agronominiai veiksniai turèjo įtakos derliaus dydžiui ir kokybei. Didžiausias grūdu derlius gautas veislès 'Badengold', 'Ceralio', 'Frankenkorn' ir 'Ostro' kviečių, o derliaus kokybès atžvilgiu pačios vertingiausios buvo veislès 'Ceralio' ir 'Ostro'. Speltos kviečių grūdų derlius buvo žymiai mažesnis taikant minimalų žemès dirbimą nei žemę dirbant tradiciškai, tačiau tirtos veislès nevienodai reagavo ị šį veiksnị. Palyginus su tradiciniu žemès dirbimu, didžiausias derliaus sumažèjimas nustatytas veisliu 'Oberkulmer Rotkorn', 'Spelt I.N.Z.' ir 'Schwabenkorn', mažiausias - veislès 'Ceralio' kviečių. Kita vertus, neariminis žemės dirbimas lèmė žymų Zeleny sedimentacijos vertės ir grūdų baltymų bei glitimo kiekio padidejjimą, o krakmolo kiekis sumažejo. Aminorūgščių kiekis grūduose buvo panašus taikant abi žemès dirbimo sistemas. Augalų cheminė apsauga reikšmingai padidino Zeleny sedimentacijos vertę ir grūdų baltymų kiekị. Taip pat padidėjo varpu skaičius $1 \mathrm{~m}^{2}$ ir grūdu derlius, o didžiausias derliaus priedas, palyginus su variantu be cheminių augalų apsaugos produktų, buvo nustatytas veislių 'Schwabenkorn', 'Spelt I.N.Z.' ir 'Frankenkorn' kviečių grūdų.

Reikšminiai žodžiai: aminorūgščių kiekis, derliaus struktūra, grūdų kokybè, herbicidai, neariminis žemės dirbimas. 